\title{
Application of remote sensing and GIS in landslide hazard zonation of Joshimath-Badrinath road corridor, Garhwal Himalaya, India
}

\author{
"Ghan Bahadur Shrestha ${ }^{1}$ and P. K. Champati ray ${ }^{2}$ \\ ${ }^{1}$ Mountain Risk Engineering Unit, Tribhuvan University, \\ Kirtipur, Kathmandu, Nepal \\ ${ }^{2}$ Geoscience Division, Indian Institute of Remote Sensing, \\ Dehra Dun, India \\ ("Email: shresthars2000@hotmail.com)
}

\begin{abstract}
S
In the Himalayan region, slope stability is a major concern for developmental activities. Generally, landslide hazard mapping is carried out to identify relatively stable areas for infrastructural development. In the present study, a statistical technique, called information value method, was used to characterise different geo-environmental parameters. These parameters were then integrated to produce a landslide hazard map in the Garhwal Himalaya, India. The landslide causative factors such as lithology, geomorphology, structure, land use, drainage, and anthropogenic activities were derived from high-resolution satellite images and topographic maps, and the information was integrated in a GIS. The terrain-related factors such as slope and aspect were extracted from a digital terrain model (DTM) derived from the stereo pair data of IRS-P5 Cartosat-1 acquired on 20 November 2005 . The map shows that 5\%,51\%, 39\%, 4\%, and $1 \%$ of the total study area falls in very low, low, moderate, high, and very high landslide hazard categories, respectively. The Joshimath town as well as A.T. Nala and Marwari villages are some of the most hazardous places in the study area. Similarly, Hanuman Chatti, Benakuh, Dam Site, Lambagar, Binaik Chatti, and Paturi as well as the Govindghat-Ghat and Vishnuprayag-Marwari road corridors fall in high and very high hazard zones.
\end{abstract}

\section{INTRODUCTION}

Every year, thousands of pilgrims visit the famous temple of Badrinath via the Joshimath-Badrinath road. During the monsoon period, many landslides damage the road and cause a severe loss of lives and property. In July 2004, a landslide dammed the Alaknanda River at Lambagar and washed away about $100 \mathrm{~m}$ long road stretch. The road was blocked for one month and thousands of pilgrims were rescued through a hydropower tunnel. Hence, present study was carried out to delineate the areas susceptible to such disasters. For this purpose, a landslide hazard map of the study area was prepared applying statistical methods. IRS satellite imageries were utilised to derive various parameters (such as landslides, lithology, and geomorphology) contributing to landslide hazard and they were integrated using a geographic information system (GIS).

The study area is situated in the Chamoli District of Uttaranchal State, India (Fig. 1). It lies between latitudes $30^{\circ} 30^{\prime} 53^{\prime \prime} \mathrm{N}$ and $30^{\circ} 43^{\prime} 10^{\prime \prime} \mathrm{N}$, and longitudes $79^{\circ} 27^{\prime} 51^{\prime \prime} \mathrm{E}$ and $79^{\circ} 37^{\prime} 07^{\prime \prime} \mathrm{E}$ with a total area of about $164.53 \mathrm{~km}^{2}$. The area has deep gorges and rugged mountains with the lowest altitude of about $1400 \mathrm{~m}$ at the Alaknanda-Vishnu Gad confluence and the height altitude of $6596 \mathrm{~m}$ at Peak Nilkanth. It lies in the Higher Crystalline Group of rocks in the Garhwal Himalaya bounded by the Munsiari Thrust in the southwest and a thick sequence of Tethyan sedimentary rocks in the north. The Main Central Thrust (MCT) passes just above the Joshimath town (Gururajan and Choudhuri 1999). The study area is composed of north-dipping low- to high-grade metamorphic rocks, such as garnet-mica schists, augen gneisses, banded gneisses, quartzites, and amphibolites (Kumar 1976). Two local faults are observed near Vishnuprayag and some lineaments were interpreted from the imagery.

The Alaknanda River, one of the main tributaries to the Ganges, flows in the north-south direction and meets the Dhauliganga River at Vishnuprayag. The Rishiganga, Khiraoganga, Ghritganga, Nilganga, and Laxmanganga are the snow-fed tributaries of the Alaknanda River. Between Rarang Chatti and Vishnuprayag, there are a number of waterfalls. In the study area, all streams and rivers exhibit straight courses indicating a structural control.

Solifluction plays an important role in soil formation on slopes. River terraces are one of the most prominent landforms. Frequently the Joshimath-Badrinath road runs through high (about $50 \mathrm{~m}$ ) terraces. Unpaired terraces on either side of the river indicate a tectonic control after the Late Glaciation time. The area experiences subtropical climate 


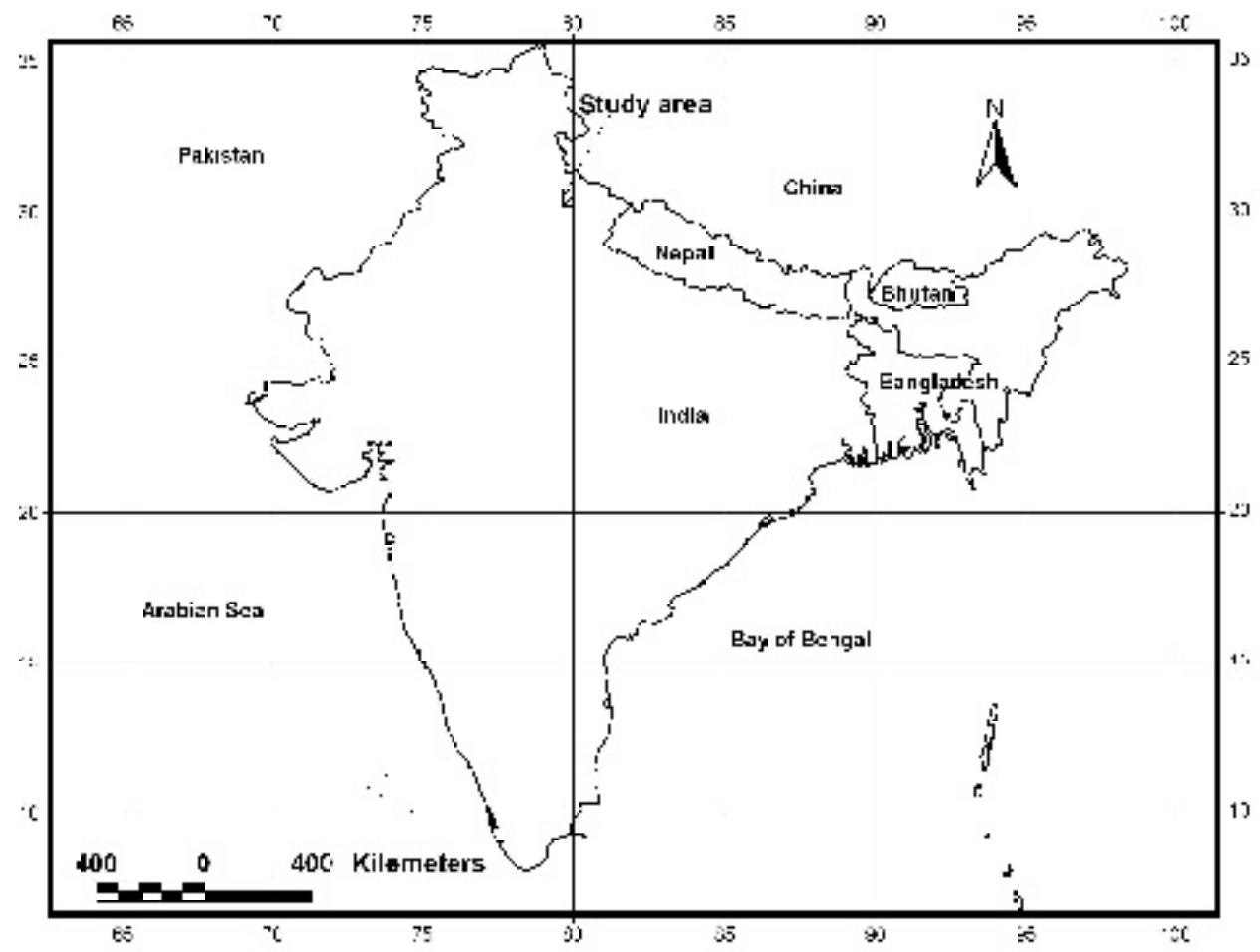

Fig. 1: Location map of the study area

with a hot and dry season in April-June, rainy season from July to September, and winter season from October to March. Snowfall from January to March is quite common in the area lying above an altitude of $2100 \mathrm{~m}$. However, even at an altitude of $1300 \mathrm{~m}$, snowfall can be observed during these months for a short interval of time. The road is disrupted frequently in winter due to heavy snowfalls, whereas it is blocked by landslides in the rainy season.

\section{IRS Satellite image interpretation}

For the purpose of landslide hazard mapping, satellite images (IRS-P5 Cartosat-1 acquired on 20 November 2005 of $2.5 \mathrm{~m}$ spatial resolution, IRS-P6 Resourcesat-1 acquired on 10 January 2005 of $5.6 \mathrm{~m}$ spatial resolution, and IRS-1C PAN acquired in 1998 of $5.8 \mathrm{~m}$ spatial resolution) were used to extract various thematic layers. For this purpose, Cartosat PAN ortho images and a digital terrain model (DTM) were obtained from the stereo pair of Cartosat-1. Six ground control points and other additional information was taken from the topographic maps (i.e. Sheets 53 N/6 and 53N/10 on scale 1:50 000).

Mainly a visual interpretation of multi-spectral and PAN images was carried out to extract various thematic layers. For land use and land cover mapping, the IRS-P6 image gave better results. Landforms were interpreted from the IRS-P6 image. Lineaments were mapped on the IRS-P6 FCC image. Ridge offsets, sharp topographic breaks, and straight stream courses were used to identify the faults. The instabilities around Lambagar were mapped using the IRS IC PAN and
IRS-P6 images. Drainage, contours (20 m interval), settlements, spot heights, and waterfalls were obtained from the topographic maps.

All the above thematic layers were finally transferred onto the large-scale $(1: 10,000)$ Cartosat PAN ortho image. In this process, necessary rectification and modification of the data were also carried out. The DTM was used to prepare a slope map and an aspect map as well as to delineate old and small landslide scars. All the above layers were further verified and corrected in the field in May 2005.

\section{Spatial distribution of instabilities}

Joshimath, A.T. Nala, Lambagar, and road corridors of the study area are severely affected by rockslides, rock falls, debris flows, and active gullies. The landslides in the study area occupy about $1.65 \mathrm{~km}^{2}$. Some of the important ones are described below.

\section{Subsidence at Joshimath}

The Joshimath town is situated on an old, dormant rotational slide. Active and old scars are clearly outlined on the Cartosat PAN ortho image. Some old landslides and unclear scars were mapped using slope profiles (Shrestha 2006) and ground data (Fig. 2). The aspect of entire slope is essentially due north-east and it is smooth, straight to slightly convex. The slope generally consists of old colluvial soils of about $10 \mathrm{~m}$ depth. 

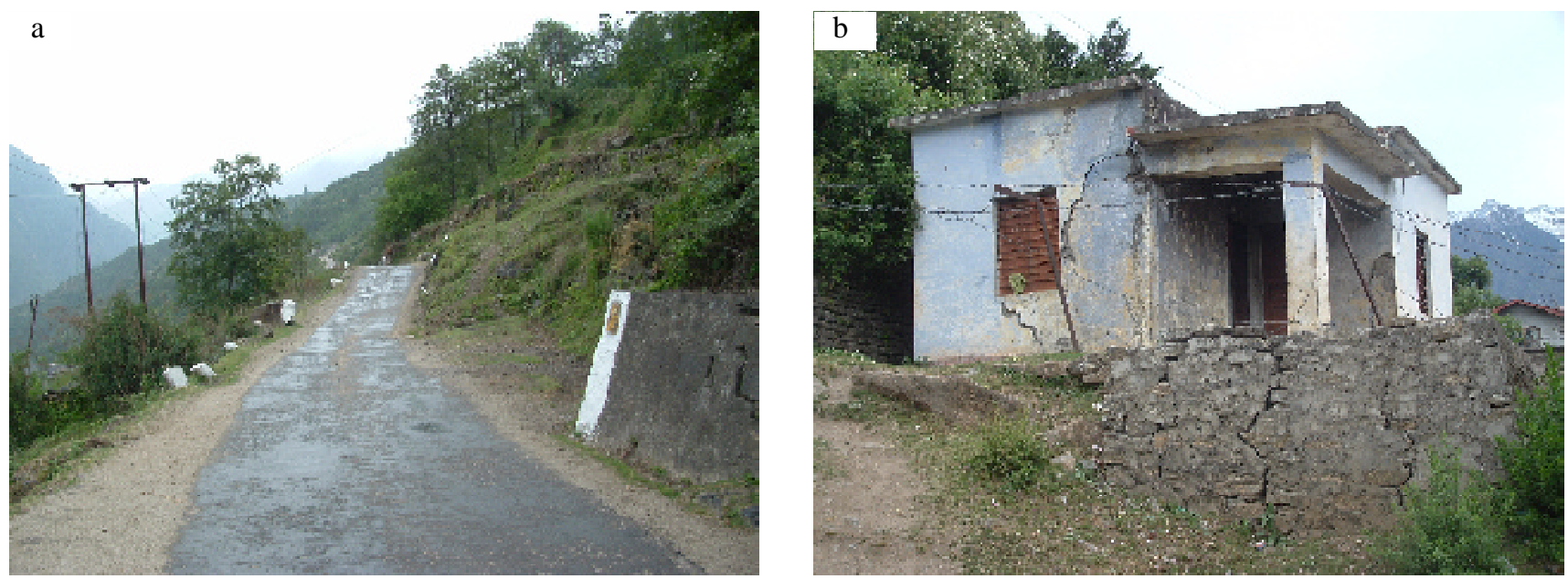

Fig. 2a: Road sinking due to a large rotational slide at Oucha, view to W; Fig. 2b: A cracked house due to ground subsidence at Joshimath

\section{A. T. Nala debris slides}

Major problems at the A.T. Nala area are caused by intense gully erosion and rotational debris slides (Fig. 3). In the monsoon period, huge debris masses block the Joshimath-Tapowan road. The slope consists of sandy clayey gravel derived from moderately weathered gneisses. The slope gradient is about $15^{\circ}$, concave-shaped, and it is facing due NE. The middle part of the slide is still moving. Seeps and springs are also contributing to the slope movement. Below the road, a narrow and deep gully contains many large boulders, which are the remnants of a past debris flow. A few houses are still at a high risk of sliding. Many new as well as old scars are prominent on the Cartosat PAN ortho image.

\section{Landslides at Lambagar}

In this area, three large rockslides (Fig. 4) occurred in July 2004 and they coalesced to form a huge debris slide downstream. The debris slide blocked the Alaknanda River for 24 hours and about $100 \mathrm{~m}$ long road stretch was washed away. Failures were triggered by the porewater pressure developed in the jointed rock mass. A comparison of IRS 1C PAN (taken in 1998) and IRS P6 LISS VI (taken in 2005) temporal images revealed that the three rockslides are rapidly enlarging owing to their headward erosion (Fig. 5).

There is also a debris slide ata distance of about $25 \mathrm{~km}$ from Joshimath towards Badrinath. The slide is $405 \mathrm{~m}$ wide and $110 \mathrm{~m}$ long. It is composed of loose, ill-sorted, angular, and slightly weathered till with clasts reaching up to $7 \mathrm{~m}$ in size. The slopes are highly susceptible to sliding and the road is damaged every year, especially during the monsoon season.

\section{LANDSLIDE HAZARD ZONATION}

In the present study, spatial statistical prognostic modelling for landslide hazard zonation was used to prepare a landslide hazard map. Similar techniques have been applied successfully in China, Italy, and many other countries (IIRS 2005). For landslide hazard zonation, the information value (Yin and Yan 1988) of different themes was calculated applying the following equation.

$$
I_{A, J \rightarrow T}=\log \left(\frac{S_{i} / N_{i}}{S / N}\right)
$$

where $I_{A, J \rightarrow T}=$ information provided by feature A and state $\mathrm{j}$ for event $\mathrm{T}$ to happen, $N=$ total number of grids in the study area, $N_{i}=$ number of grids having variable $I, S=$ total number of landslide-occurring grids in the entire study area, and $S_{i}=$ number of landslide-occurring grids within the " $I$ " variable grids.

The following nine overlays were selected for landslide hazard zonation:

- geology, geomorphology,

- lineament density,

- drainage density,

- slope,

- aspect,

- land use,

- cut slope failure, and

- fault zone.

For this purpose, vector files were converted into raster overlays with an individual sell size of $20 \mathrm{~m}$. The information 


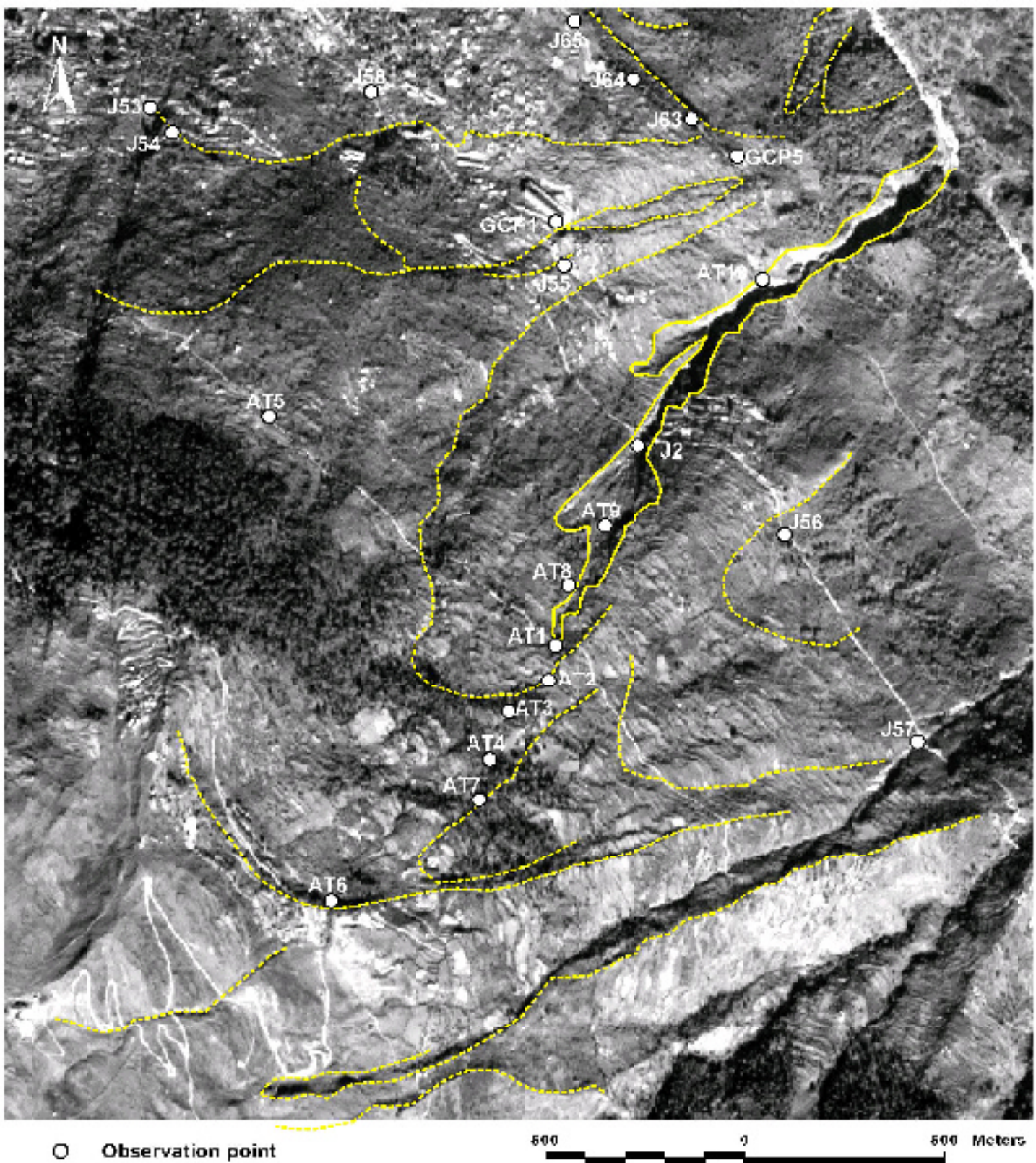

Fig. 3: Ortho image of A. T. Nala landslide. Dashed and solid lines show old and active scars respectively.

value of a thematic layer (Table 1) was calculated from the above equation and all the thematic values were then summed up to obtain a combined value map. The final landslide hazard map (Fig. 6) was prepared by reclassifying the map into five hazard categories (Table 2 ). The very low, low, moderate, high, and very high landslide hazard categories occupy respectively $5 \%, 51 \%$, $39 \%, 4 \%$, and $1 \%$ of the total study area. Similarly, $22 \%$, $41 \%, 25 \%, 11 \%$, and $1 \%$ of the landslide area falls in the very high, high, moderate, low, and very low hazard zones respectively. About $63 \%$ of the total landslide area in the Joshimath-Badrinath road corridor falls within $5 \%$ of the high and very high hazard zones. About $90 \%$ of the landslide area around Joshimath and A. T. Nala falls within the very high and high hazard zones. Similarly, the landslides between Vishnuprayag and Marwari fall in high hazard zones, whereas at Lambagar, $70 \%$ of the landslide area falls in the high and very high hazard zones. Joshimath, A.T. Nala, and Marwari fall in high and very high hazard zones. Similarly, Hanuman Chatti, Benakuh, Dam Site, Lambagar, Binaik Chatti, and Paturi also belong to highly hazardous areas. The road corridor between Govindghat and Ghat as well as between Vishnuprayag and Marwari falls in very high and high hazard zones. 


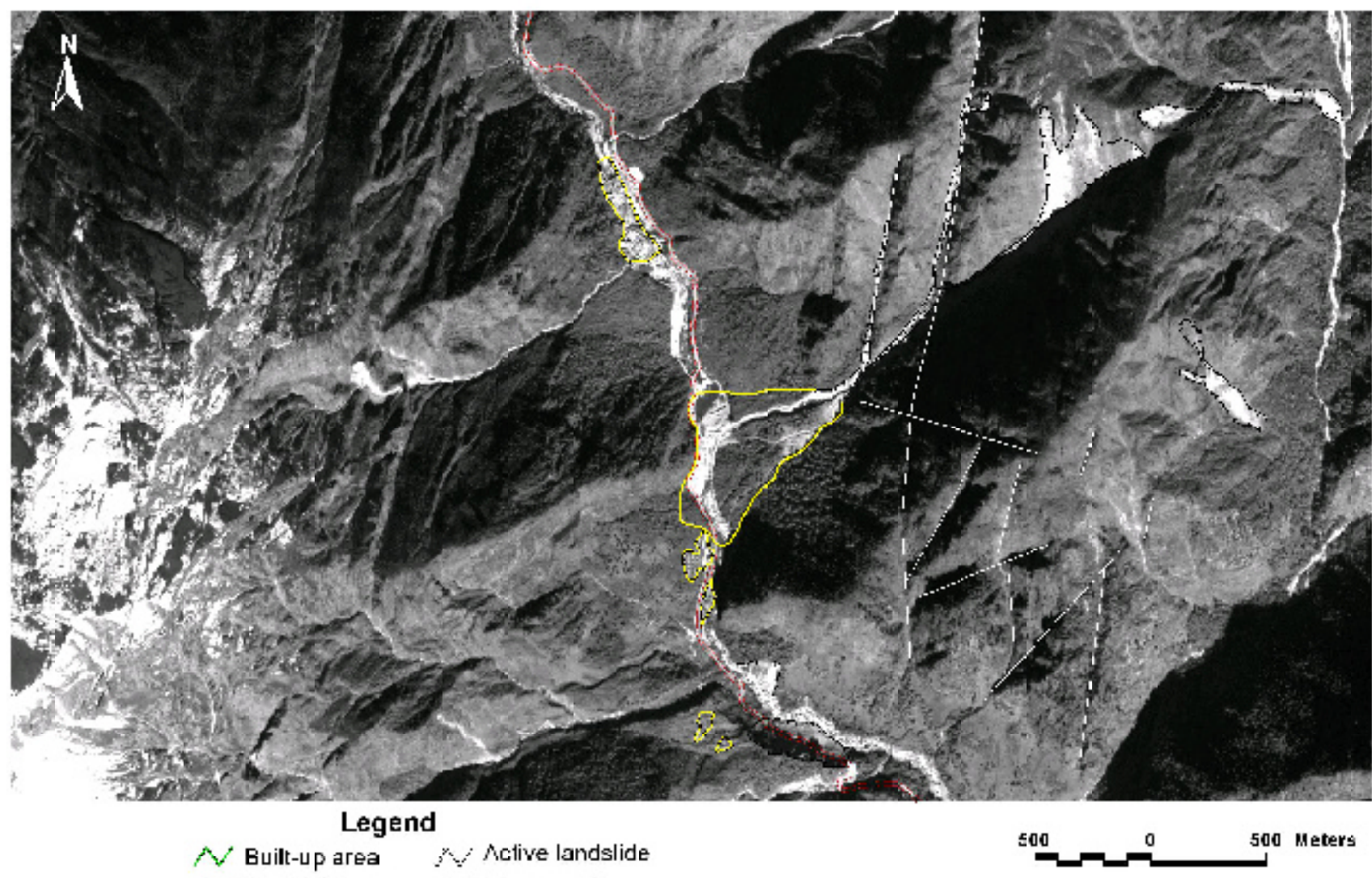

Fig. 4: A landslide damming the Alaknanda River at Lambagar (in the centre of image). Three rockslides form a cone-shaped debris fan downstream (Cartosat PAN Ortho image of 20 Nov. 2005)
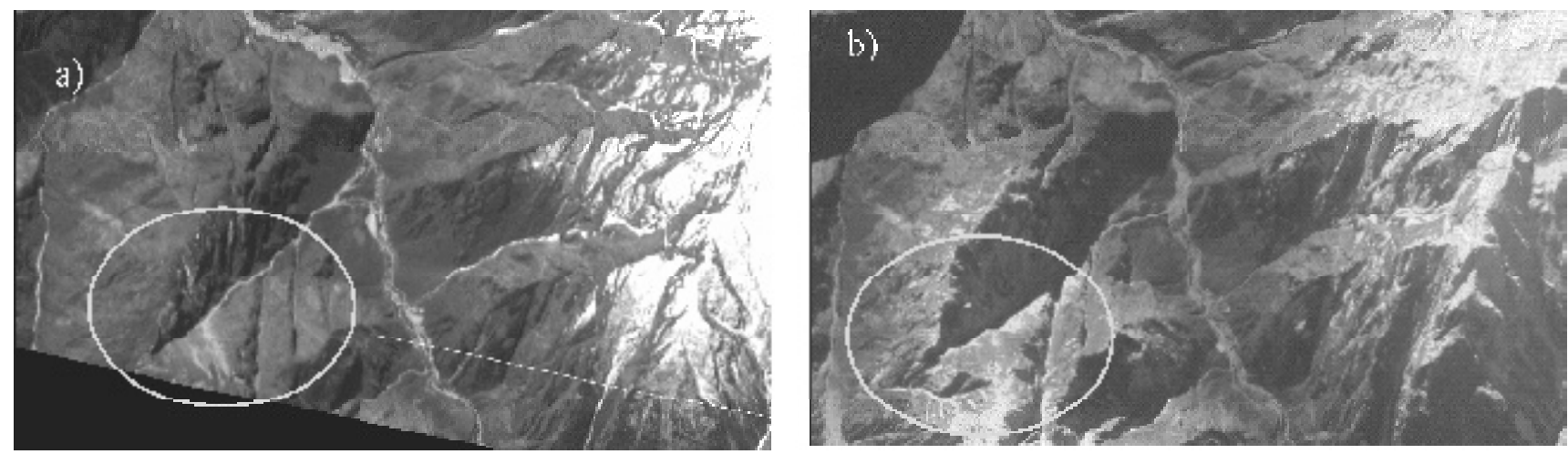

Fig. 5: Status of landslides at Lambagar. a) Landslide observed on IRS 1C PAN of 1998 and b) the same landslide observed on IRS P6 LISS VI of 2005. 
Table 1: Information values obtained for different thematic layers

\begin{tabular}{|c|c|c|c|c|c|}
\hline S. N. & Variables/attributes & Values & S. N. & Variables/attributes & Values \\
\hline \multirow[t]{5}{*}{1} & Geology & & \multirow[t]{5}{*}{5} & Faults/thrusts & \\
\hline & Granitic gneiss & -0.240 & & $\mathrm{~T} 1(100 \mathrm{~m})$ & 0.639 \\
\hline & Quartzite & 0.120 & & $\mathrm{~T} 2(200 \mathrm{~m})$ & 0.535 \\
\hline & Gneiss & -0.170 & & $\mathrm{~F} 1(75 \mathrm{~m})$ & 0.017 \\
\hline & Mica schist & 0.310 & & $\mathrm{~F} 2(150 \mathrm{~m})$ & -0.405 \\
\hline \multirow[t]{11}{*}{2} & Land use/land cover & & \multirow[t]{5}{*}{6} & Lineament density & \\
\hline & Snow & 0.000 & & Very low & -0.293 \\
\hline & Barren land & -0.094 & & Low & 0.152 \\
\hline & Grass land & -0.106 & & Moderate & -0.102 \\
\hline & River bed & -0.335 & & High & -0.524 \\
\hline & Moderate vegetation & -0.057 & \multirow[t]{5}{*}{7} & Drainage density & \\
\hline & Dense vegetation & 0.041 & & Very low & -0.093 \\
\hline & Scrub/grass & 0.331 & & Low & 0.002 \\
\hline & Agriculture & 0.765 & & Moderate & 0.078 \\
\hline & Degraded vegetation & 0.818 & & High & 0.000 \\
\hline & Built-up area & -0.816 & \multirow[t]{10}{*}{8} & Aspect & \\
\hline \multirow[t]{12}{*}{3} & Geomorphology & & & $\mathrm{N}(0-67)$ & 0.133 \\
\hline & $\begin{array}{l}\text { Highly dissected denudational structural } \\
\text { slope (HDDSS) }\end{array}$ & -0.717 & & NE (67-112) & 0.111 \\
\hline & $\begin{array}{lrr}\text { Moderately } & \text { dissected } & \text { denudational } \\
\text { structural slope } & (\text { MDDSS) } & \end{array}$ & 0.124 & & $\mathrm{E}(112-157)$ & -0.126 \\
\hline & $\begin{array}{l}\text { Less dissected denudational structural } \\
\text { slope (LDDSS) }\end{array}$ & -0.078 & & SE (157-202) & 0.163 \\
\hline & Glacio-fluvial & -0.275 & & S (202-247) & 0.040 \\
\hline & River bed & 0.136 & & SW (247-292) & 0.066 \\
\hline & Bank erosion & 0.117 & & W (292-337) & -0.107 \\
\hline & Scree & 0.435 & & NW (337-360) & -0.235 \\
\hline & River terrace & 0.498 & & Flat & -0.771 \\
\hline & Till & 1.055 & & & \\
\hline & Debris fan & 1.182 & & & \\
\hline & Fan/scree & 0.000 & & & \\
\hline \multirow[t]{9}{*}{4} & Slope classes( $\left(^{0}\right)$ & & & & \\
\hline & $0-15$ & 0.032 & & & \\
\hline & $15-25$ & 0.165 & & & \\
\hline & $25-30$ & 0.130 & & & \\
\hline & $30-35$ & 0.165 & & & \\
\hline & $35-40$ & 0.013 & & & \\
\hline & $40-45$ & -0.126 & & & \\
\hline & $45-60$ & -0.405 & & & \\
\hline & $>60$ & -0.346 & & & \\
\hline
\end{tabular}

Table 2: Area occupied by landslides and their hazard categories

\begin{tabular}{l|c|c|c|c}
\hline \multirow{2}{*}{ Category } & \multicolumn{2}{|c|}{ Landslide hazard } & \multicolumn{2}{c}{ Landslide area } \\
\cline { 2 - 5 } & $\mathbf{k m}^{\mathbf{2}}$ & $\begin{array}{c}\text { Per cent of total } \\
\text { hazard area }\end{array}$ & $\mathbf{k m}^{\mathbf{2}}$ & $\begin{array}{c}\text { Per cent of total } \\
\text { landslide area }\end{array}$ \\
\hline Very high hazard & 1.6453 & 1 & 0.361966 & 22 \\
\hline High hazard & 6.5812 & 4 & 0.674573 & 41 \\
\hline Moderate & 64.1667 & 39 & 0.411325 & 25 \\
\hline Low & 83.9103 & 51 & 0.180983 & 11 \\
\hline Very low & 8.2265 & 5 & 0.016453 & 1 \\
\hline Total & $\mathbf{1 6 4 . 5 3 0 0}$ & $\mathbf{1 0 0}$ & $\mathbf{1 . 6 4 5 3 0 0}$ & $\mathbf{1 0 0}$ \\
\hline
\end{tabular}




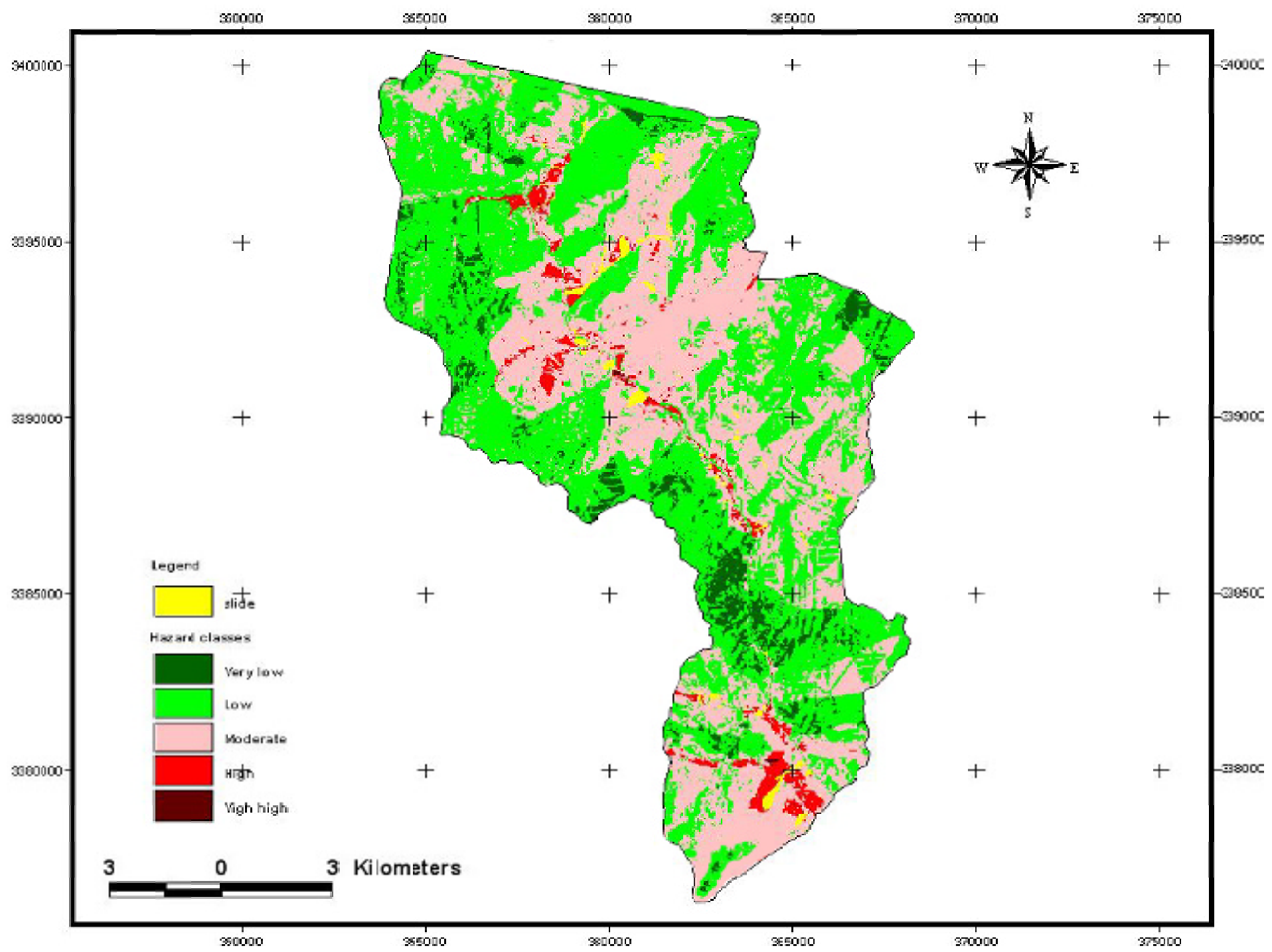

Fig. 6: Hazard map of the Joshimath-Badrinath road corridor

\section{CONCLUSIONS}

IRS-1C PAN, IRS-P6, IRS-P5 Cartosat PAN, and IRS-P6 FCC temporal images were useful for landslide hazard mapping in the Joshimath-Badrinath road corridor.

The information value method applied in this study is a simple and cost-effective tool to delineate hazardous areas in an inaccessible terrain like the Himalaya. The Joshimath town as well as A.T. Nala and Marwari villages are some of the most hazardous places in the study area. Similarly, Hanuman Chatti, Benakuh, Dam Site, Lambagar, Binaik Chatti, and Paturi as well as the Govindghat-Ghat and Vishnuprayag-Marwari road corridors also belong to high and very high hazard zones.

\section{ACKNOWLEDGEMENTS}

We are grateful to Dr. V. K. Dadhwal, Dean, IIRS, Dehra Dun, for providing computer facilities and field gear. We thank Professor R. C. Lakhera, Geosciences Division, IIRS, for his support and guidance as well as valuable suggestions during the study. Special thanks are due to Professor Ajay Kumar Naithani, Garhwal University; the staffs of Border Roads Organisation, Indian Army; and India-Tibet Border Police for providing accommodation during the fieldwork.

\section{REFERENCES}

Gururajan, N. S. and Choudhuri, 1999, Ductile thrusting, metamorphism and normal faulting in Dhauliganga Valley, Garhwal Himalaya, Himalayan Geology, v. 20(2), pp.19-29 
IIRS, 2005, Lectures note, RS and GIS applications in Geosciences, Geosciences Division, Indian Institute of Remote sensing, Dehra Dun, India, 290p.

Kumar, G., 1976, Geology and Sulphide mineralisation in the Porkhari area, Chamoli District, Utter Pradesh, Geol. Surv. India, Misc. Pub. 16, pp. 92-98

Shrestha, G. B., 2006, Geotechnical characterisation and deterministic modelling of landslides along Joshimath to
Badrinath Area, thesis submitted to Centre for Space Science and Technology Education in Asia and the pacific (affiliated to the United Nations), Indian Institute of Remote sensing, Dehra Dun, India, $40 \mathrm{p}+$.

Yin, K. L. and Yan, T. Z., 1988, Statistical Prediction Models for Slope Instability of Metamorphosed Rocks, Proc. $5^{\text {h }}$ Int. Symp. On Landslides, Lausanne, v. 2, pp. 1269-1272 